\title{
FINANCIAL TECHNOLOGIES IN PERSONAL FINANCIAL PLANNING: ROBO-ADVICE VS. HUMAN-ADVICE*
}

\section{INTRODUCTION}

The development of the financial market means the emergence of new institutions and financial instruments. Given that households generally have insufficient financial knowledge, there is an increased demand for professional financial advice; and since the wealth of the society is held in environments of low interest rates, this generates a demand for advice on financial instruments and investments, and asset management services. The financialization of households is a factor that makes financial decisions key for them, affecting their level of well-being. The modern democratization of access to consumer and mortgage loans by households increases the demand for professional credit counselling and debt management, and for assistance with the inefficiency of state saving systems for old-age security.

The purpose of this article is to discuss the use of financial technologies in personal financial planning with the use of robo-advice. The article is based on a broad review of the literature and research. The research problem focuses on the perception of robo-advisers by traditional, human, certified financial advisors, and on the prospects for robo-consultancy development in Poland. The authors seek to confirm the hypothesis that robo-advisors are more of an opportunity than a threat to human financial advisors, and to suggest that in the future a hybrid consulting model will dominate, in which a traditional advisor uses modern technologies and robo-advice as a tool for his or her work with clients. Roboadvice will complement traditional counselling as a complementary component.

\section{PERSONAL FINANCIAL PLANNING (PFP): THE ESSENCE, ELEMENTS, IMPORTANCE FOR HOUSEHOLDS}

Households have limited resources, which they use to meet the needs - collective and individual - of their members. One of the most important decisionmaking areas of a household, affecting the extent to which its needs are satisfied, is the financial field. It is here that everyday decisions are made regarding

* The project financed within the Regional Initiative for Excellence programme of the Minister of Science and Higher Education of Poland, years 2019-2022, grant no. 004/RID/2018/19, financing 3,000,000 PLN. 
consumption and savings, allocating part of savings for investments, sources of financing current and housing needs, decisions on risk management and insurance, retirement and estate planning, tax planning, cash flow and budget control, and thus financial liquidity management. The low level of financial knowledge affects the relatively small interest in personal finance management, which includes personal finance planning. Financial decisions taken by households not only affect them alone; they also have macroeconomic significance in shaping consumption, savings, investment and credit in the economy. ${ }^{1}$

Personal financial planning is defined as the process designed to enable consumers to achieve their short, medium and long-term personal financial goals, which may be quantitative or qualitative in nature. A personal financial plan is a document that specifies how a consumer should organize and manage his or her personal financial affairs, in whole or in part, so as to satisfy present and future personal goals, needs and priorities. A personal financial planner (financial planning practitioner) is an individual who provides a service of personal financial planning to clients, and who meets all of the ethics, competence and experience requirements contained in this International Standard. ${ }^{2}$

Personal financial planning facilitates better liquidity management (Scheme 1), better spending, control of money, liquidity management and accumulation of wealth. When building a financial plan for a household, one usually needs to take a number of risk factors into account. These are the factors that have influence on the shape of the future term structure of household incomes and expenditures. The factors may be of a very differentiated nature, which means that their impact on the cash-flow term structure may be different, both in terms of the underlying mechanism and strength. ${ }^{3}$

\section{Scheme 1}

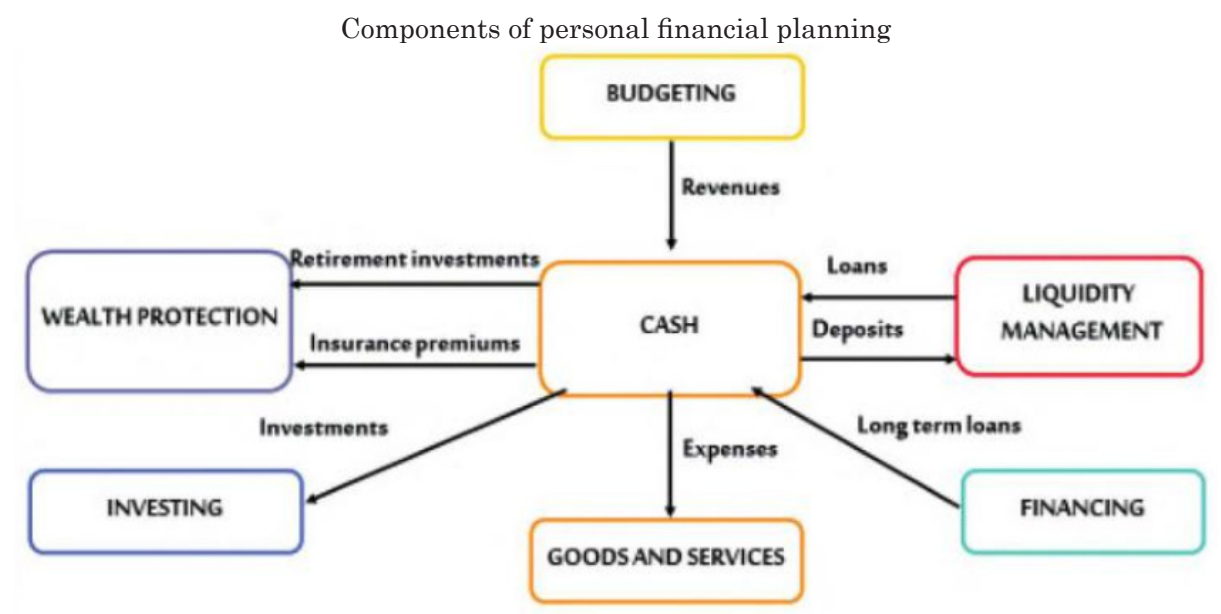

Source: Madura (2014): 9.

\footnotetext{
1 Waliszewski (2014): 112.

${ }^{2}$ ISO 22222 (2005): 8.

${ }^{3}$ Pietrzyk, Rokita (2018): 60.
} 
Financial planning is individualized (directed towards a particular household); it takes into account the life cycle of a household (its members) and should be conducted not only for wealthy households. It is a dynamic process, which should be monitored and adjusted whenever necessary. ${ }^{4}$

The concept of personal financial planning has been developed, and, currently, according to the international standard ISO 22222: 2005, consists of six phases:

1. Establishing and defining the client and personal financial planner relationship.

2. Gathering client data and determining goals and expectations.

3. Analysing and evaluating the client's financial status.

4. Developing and presenting the financial plan.

5. Implementing the financial planning recommendations.

6. Monitoring the financial plan and the financial planning relationship.

Personal financial planning can be carried out on one's own, but it is more effective to hire a financial advisor - a financial market specialist who abides by ethical principles. ${ }^{5}$ Personal financial planning is a holistic approach to the financial decisions of households in at least two dimensions - it covers the most important areas related to personal finances, and additionally takes into account the changing needs and financial goals of the household throughout its life cycle. The main instruments of personal financial planning include a personal financial plan and financial statements: a personal balance sheet, personal cash flow and a personal budget. ${ }^{6}$ The research conducted in Poland shows that despite wide access to modern technologies, as well as to financial knowledge, most households declare that they do not plan personal finances because they have everything under control or there is no time for it. ${ }^{7}$ In practice, this means that households all too often fall into financial problems related to over-indebtedness and insolvency. ${ }^{8}$ In the process of personal financial planning on the household scale, financial literacy, which includes financial knowledge, financial competences and financial attitudes, is of fundamental importance. ${ }^{9}$

Preceding the analysis of the influence of financial knowledge on the propensity to make financial decisions and engage in planning is the measurement of knowledge in the examined society. According to the literature on the subject, ${ }^{10}$ this involves the study of knowledge in the field of risk diversification, calculation skills in the context of investment, folding percentage, inflation, and prize distribution.

The ability to plan finances in the long term is a very important skill, since it is difficult to save effectively and make proper calculations of sav-

\footnotetext{
${ }^{4}$ Jajuga et al. (2015): 25.

${ }^{5}$ Waliszewski (2016): 67; Mitek (2016): 75.

${ }^{6}$ Musiał (2018): 55.

${ }^{7}$ Samsel (2019): 61.

8 Wiśniewska (2016): 95.

${ }^{9}$ Świecka (2018): 10.

${ }^{10}$ Lusardi, Mitchell (2011): 12.
} 
ings created with a view to future retirement without it. The starting point for identifying the specific groups of recipients of educational activities in all areas of finance should be the identification of each social group, especially those with the lowest levels of financial knowledge. Initiatives addressed to the interested groups should communicate, among other things, the need to put aside private savings for future retirement, the offer of various financial institutions and possible tax benefits, but also the need to create long-term financial plans. Undoubtedly, a feature that determines the effectiveness of financial education is its adjustment to the moment of life, place of residence, expectations of the individual and the whole household, and their needs and threats resulting from belonging to a given social group. Bearing in mind the effectiveness of the initiatives undertaken in this regard, one should remember to demonstrate the benefits arising from the ability to defer current benefits and the great role of self-control and willpower necessary to implement the plans. ${ }^{11}$

Modern technologies contribute to increasing household efficiency. Thanks to technologies, household members are able to use their time rationally, improve their financial management skills, and make optimal financial decisions. On the other hand, uncritical submission to technological novelties (information, communication) may lead to negative consequences. ${ }^{12}$ The use of modern technologies (not only as part of activities in financial education, but also as part of the core business of financial institutions) is a factor encouraging household members, who use similar tools. In the case of such groups of clients, the lack of electronic banking in the offer of a given institution may lead to a decision on self-exclusion. What seems to be even more important, however, are the various types of applications that facilitate the management of personal finances and facilitate planning of expenses. ${ }^{13}$

\section{FINANCIAL TECHNOLOGIES IN PERSONAL FINANCIAL PLANNING}

The development of modern technologies is first applicable in the area of retail financial services. A new segment on the financial services market has emerged, known as financial technologies (fin-tech), consisting of start-ups not subject to such restrictive regulations as traditional financial institutions, with more flexible offers made available to customers through mobile distribution channels. The most important fin-tech applications relate to the area of financing, asset management, including robo-advice and PFM applications, payments and other segments, for example insurance (Scheme 2). The fin-tech

\footnotetext{
11 Swacha-Lech (2016): 480.

12 Włodarczyk-Śpiewak (2011): 147.

${ }^{13}$ Cichowicz (2016): 76.
} 
sector is developing, as young consumers enter the financial services market. They are not attached to traditional banks and appreciate flexible, convenient and time-saving service.

\section{Scheme 2}

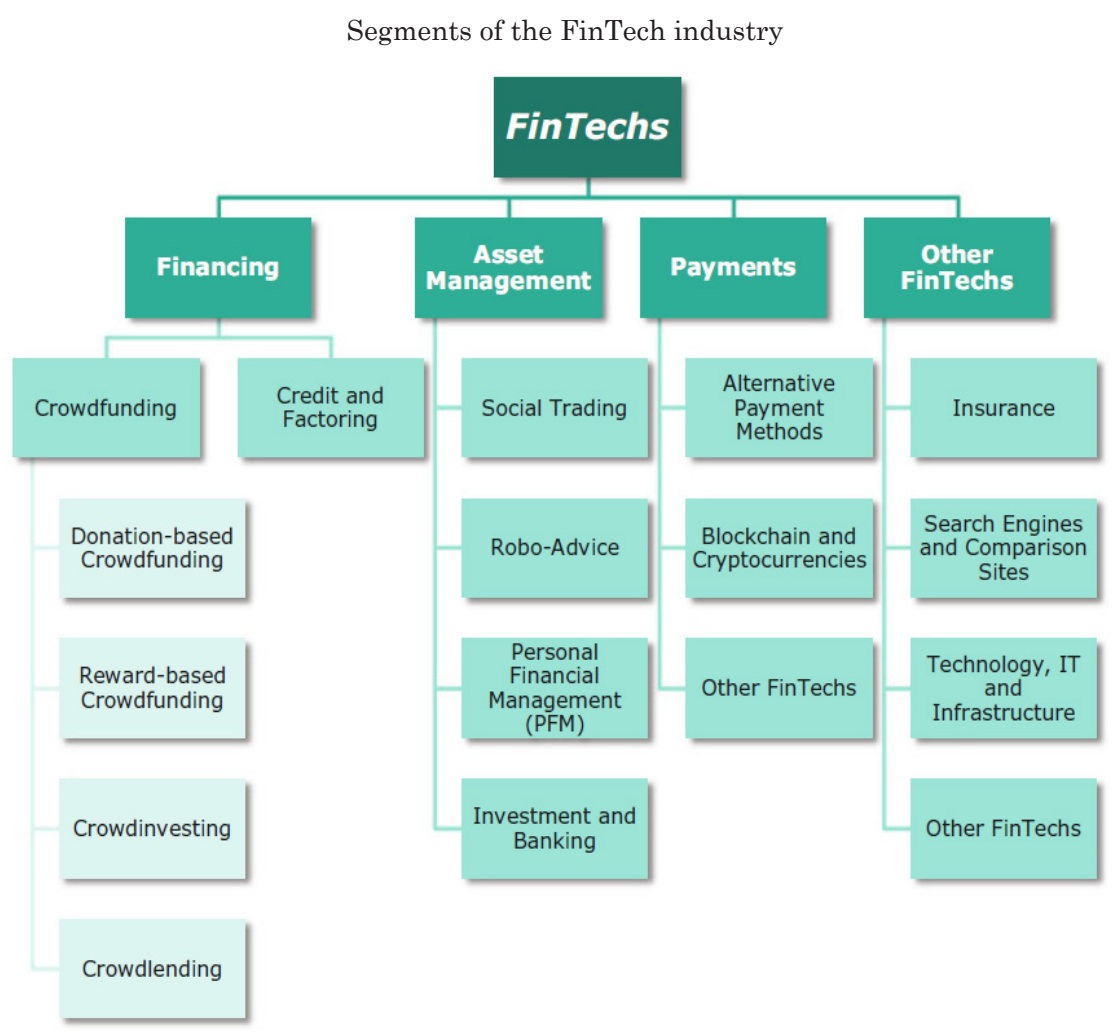

Source: Dorfleitner et al. (2017): 7.

Fintech means the use of technology to deliver financial services and products to consumers in the area of banking, insurance, and investing. FinTech is coming to represent technologies that are disrupting traditional financial services, and includes mobile payments, money transfers, loans, fundraising and asset management. ${ }^{14}$ FinTech is a part of modern finance, called Finance 4.0 in the economy of the Fourth Industrial Revolution (Industry 4.0). FinTech poses a challenge for regulators, who have to find balance between protecting financial market participants and creating opportunities for the development of the modern finance sector. Financial

${ }^{14}$ Madir (2019): 200. 
supervision uses regulatory sandboxes ${ }^{15}$ and innovation hubs ${ }^{16}$ in FinTech regulation. ${ }^{17}$

It should be pointed out that this represents a functional perspective, which differs from the institutional perspective that sees FinTech as specific types of start-up businesses. This functional perspective opens the view to three sub-areas of FinTech: InsurTech, connected with using financial technology in the insurance sector, RegTech, meaning the usage of financial technology to comply with regulations, and BankTech: consumer decisions in retail banking and robo-advisor platforms. PFM and robo-advice are a part of consumer decisions in retail banking, which uses financial technology.

Banks, interbank entities and other financial institutions play an important role in the development of the fintech market. Apart from innovation, the elements of the competitive advantage of FinTech industry entities include simplified procedures, relatively low commissions and modern technological solutions. The development of the potential of modern solutions requires an appropriate scale of business and consumer confidence - these elements are owned by banks. Banks now see the need for cooperation in implementing technological innovations. ${ }^{18}$ Trust, and therefore the expectation of the credibility of a word, promise, oral or written promise of another entity or group, is even more important in the case of the FinTech sector because it mainly functions in the virtual world. ${ }^{19}$

Importantly, the principle of FinTech entities is to introduce technological innovations from the outside to the inside rather than from the inside to the outside. This means that the implementation of innovative changes is subordinated primarily to removing negative ones and creating positive customer experiences that arise during the use of company services. The emergence of FinTech entities is a response to the gaps that appeared in the product offer and services provided by traditional entities. The recipients of financial services expect financial institutions to quickly adjust their products and services to individual, often changing, needs. ${ }^{20}$ Nowadays, the broad interest of FinTech companies in the payment market and financial management is mainly due to the previous negligence of banks in the development of this area.

15 Regulatory sandboxes provide a scheme to enable firms to test, pursuant to a specific testing plan agreed and monitored by a dedicated function of the competent authority, innovative financial products, financial services or business models.

${ }^{16}$ Innovation hubs provide a dedicated point of contact for firms to raise enquiries with competent authorities on FinTech-related issues and to seek non-binding guidance on the conformity of innovative financial products, financial services or business models with licensing or registration requirements and regulatory and supervisory expectations.

17 Report FinTech (2018).

18 Górna, Warchlewska (2018): 290.

19 Świeszczak (2017): 146.

${ }^{20}$ Milic-Czerniak (2019): 51. 


\section{ROBO-ADVICE AS AUTOMATED FINANCIAL ADVICE: A RESEARCH OVERVIEW}

New technologies became more extensively applied in the financial industry particularly after the 2007-08 global financial crisis, when tighter regulations on traditional banks and developments in computer science increased incentives to develop non-bank, technology-based financial companies. Technological disruption has reached the realm of wealth management services, where automated financial advisors, known as robo-advisors (RA), are starting to compete with human advisors. ${ }^{21}$ The first automated financial advisor, Betterment, was launched in 2010 by Jon Stein, a 30-year old entrepreneur in the US, which is the home of RA and, so far, the leading market for robo-advisors. The popularity of robo-advisors is starting to grow in other parts of the world, and thus in Europe and in Asia: China (mainland), Hong Kong SAR - China, India, Japan, Singapore, Thailand, and Vietnam. According to Statista.com, assets under management in the Robo-Advisors segment amount to US $\$ 1,442,028 \mathrm{~m}$ in 2020 , with 70,509 in 2019 users and a penetration rate of $0.9 \%$, and are expected to show an annual growth rate (CAGR 2020-2023) of $21.0 \%$, resulting in the total amount of US $\$ 2,552,265 \mathrm{~m}$ by 2023 , and 147,018 thousand users, and a penetration rate of $1.9 \%$.

An overview of the literature on robo-advisor definitions (Table 1) shows the characteristic features of robo-advisors that distinguish them from human advisors. They are:

- digital platforms based on quantitative algorithms using investor characteristics, including the assessments of individual risk aversion;

- without human interaction; used in portfolio and assets management, based on passive and cost-efficient instruments most often EFTs, while efficiently managing these allocations by rebalancing mechanisms;

- intended to serve the needs of the mass market.

The main advantage of robo-advisors over human advisors are lower costs and a lower or no required investment threshold. The main disadvantage is the lack of contact with a human adviser and solutions that are not fully adapted to the investor's situation and risk profile, because the survey he or she completes does not reflect the client's overall finances. ${ }^{22}$ In addition, the short duration of their operation means that it is not known what results are achieved during a crisis compared to traditional solutions. These disadvantages mean that the most common model is a hybrid, namely the combination of a human advisor and a robo-advisor, where technological solutions are a work tool in financial consulting and personal financial planning, and this model will dominate in the future.

\footnotetext{
21 Facundo, Schmukler, Tessada (2019): 2.

22 Jung, Glaser, Köpplin (2019): 415.
} 
Table 1

Review of the definition of robo-advisor

\begin{tabular}{|l|l|}
\hline \multicolumn{1}{|c|}{ Author } & \multicolumn{1}{c|}{ Meaning } \\
\hline $\begin{array}{l}\text { M. Faloon } \\
\text { B. Scherer }\end{array}$ & $\begin{array}{l}\text { Automated asset management advisory firms; they assign risky portfolios } \\
\text { to individual investors based on investment algorithms. These algorithms } \\
\text { use investor characteristics such as age, net income, and the assessments } \\
\text { of individual risk aversion to recommend suitable asset allocations. Client } \\
\text { interaction and the delivery of portfolio advice are web-based and without } \\
\text { human interaction. Robo-advice disintermediates the classical distribu- } \\
\text { tion model, which is now widely recognized as expensive, difficult to scale, } \\
\text { and unacceptably heterogeneous (i.e. highly dependent on the individual } \\
\text { advisor's skill level). }\end{array}$ \\
\hline $\begin{array}{l}\text { L. Brenner } \\
\text { T. Meyll }\end{array}$ & $\begin{array}{l}\text { Robo-advisors ask the clients for information on their financial situation } \\
\text { and their investment objectives, subsequently creating an investment } \\
\text { portfolio suitable to the clients (risk-)profile often using inexpensive ex- } \\
\text { change traded funds (ETFs), and managing the portfolio usually based on } \\
\text { an algorithm, which includes, for example, rebalancing activities and the } \\
\text { reinvesting of dividends or savings plan inflows. }\end{array}$ \\
\hline M.L. Fein & $\begin{array}{l}\text { The term 'robo-advisor' refers to any of a growing number of Internet-based } \\
\text { investment advisory services aimed at retail investors that have emerged } \\
\text { in the financial marketplace in recent months. About a dozen or so of such } \\
\text { services currently exist with a significant customer base. More robo-advi- } \\
\text { sors are expected to appear in the future. }\end{array}$ \\
\hline P. Sironi & $\begin{array}{l}\text { Robo-Advisors (1.0) are automated investment solutions which engage } \\
\text { individuals with digital tools featuring advanced customer experience to } \\
\text { guide them through a self-assessment process and shape their investment } \\
\text { behaviour towards rudimentary goal-based decision-making, conveniently } \\
\text { supported by portfolio rebalancing techniques using trading algorithms } \\
\text { based on passive investments and diversification strategies. }\end{array}$ \\
\hline
\end{tabular}

Source: Fein (2015): 20; Sironi (2016): 36; Brenner, Meyll (2020): 5; Faloon, Scherer (2017): 31.

We can distinguish four stages in the evolution of robo-advice services, which can be classed as robo-advice 1.0, 2.0, 3.0, 4.0. The differences in them relate to the forms of communication with the client, the scope of activities performed for the client, and ways of making the final decision. Research shows that currently $80 \%$ the available robo-advice solutions are in phase 3.0 and $11 \%$ are in phase $1.0,4 \%$ in phase 2.0 and $2 \%$ in phase $4.0 .{ }^{23}$ The use of a robo-advisor reduces the number of stages associated with the provision of financial advisory services from the previously indicated six to three, which consist of configuration, matching and customization, and maintenance ${ }^{24}$. An overview of studies presented in Table 2 provides us with some very interesting information on the market of automatic financial advisory service.

23 Deloitte (2016): 4.

24 Jung et al. (2018): 83. 
Table 2

Selected research on robo-advice in Poland and worldwide

\begin{tabular}{|c|c|c|c|}
\hline Year & $\begin{array}{l}\text { Author of } \\
\text { the study/ } \\
\text { report }\end{array}$ & $\begin{array}{l}\text { Subject of } \\
\text { the study }\end{array}$ & Main conclusions of the study \\
\hline 2018 & D. Kordela & Germany & $\begin{array}{l}\text { The German market is dominated by companies } \\
\text { offering active management ( } 42 \% \text { ), while companies } \\
\text { offering only passive management account for } 25 \% \\
\text { of service providers, and } 19 \% \text { of companies offer both } \\
\text { options - clients can choose between active and passive } \\
\text { management styles. The results of the analyses indi- } \\
\text { cate that about } 80 \% \text { of robo-advisors on the German } \\
\text { market are service providers that offer the } 3.0 \text { level. }\end{array}$ \\
\hline 2018 & $\begin{array}{l}\text { M. Fulk } \\
\text { J. E. Grable } \\
\text { K. Watkins } \\
\text { \& M. Kruger }\end{array}$ & $\begin{array}{l}\text { U.S. consu- } \\
\text { mers }\end{array}$ & $\begin{array}{l}\text { The findings showed a difference between those } \\
\text { who used robo-advisory services and those who used } \\
\text { traditional financial planning services. The results } \\
\text { showed that users of robo-advisory services generally: } \\
\text { (1) had lower income, } \\
\text { (2) had lower net worth, } \\
\text { (3) had received no or less inheritance, and } \\
\text { (4) were less impulsive financially. }\end{array}$ \\
\hline 2018 & $\begin{array}{l}\text { M. Beketov } \\
\text { K. Lehmann } \\
\text { M. Wittke }\end{array}$ & $\begin{array}{l}219 \text { systems } \\
\text { that could be } \\
\text { considered as } \\
\text { robo-advisors }\end{array}$ & $\begin{array}{l}\text { Most of the current RAs use Modern Portfolio Theory } \\
\text { (about } 40 \% \text { ) and, importantly, they tend to improve } \\
\text { and augment this framework rather than applying and } \\
\text { developing entirely new approaches. The companies } \\
\text { using relatively sophisticated methods attract higher } \\
\text { AuM volumes despite the fact that these methods are } \\
\text { applied less often than the simpler and more gene- } \\
\text { rally defined methods. More generally, the overall } \\
\text { comparison of the RA methodological landscape with } \\
\text { the current state-of-the-art methods shows a clear } \\
\text { gap between the methods applied in RAs and newer } \\
\text { methods that are widely considered as promising and } \\
\text { scientifically justified in the literature. }\end{array}$ \\
\hline 2018 & $\begin{array}{l}\text { A. Sanders } \\
\text { Woodyard } \\
\text { J. E. Grable }\end{array}$ & US adults & $\begin{array}{l}95 \text { percent of respondents identified themselves as } \\
\text { users of a traditional financial advisory service, whe- } \\
\text { reas five per cent were exclusively robo-advisory users. } \\
\text { The results indicate that the users of robo-advisory } \\
\text { services are young and confident in their financial } \\
\text { abilities yet distrustful of the traditional channels of } \\
\text { financial advice. }\end{array}$ \\
\hline 2020 & $\begin{array}{l}\text { K. Waliszew- } \\
\text { ski } \\
\text { A. Warchlew- } \\
\text { ska }\end{array}$ & $\begin{array}{l}114 \text { users of } \\
\text { robo-advisor } \\
\text { Finax }\end{array}$ & $\begin{array}{l}\text { The type of investment strategy used, the assessment } \\
\text { of ethics, development prospects, opinions about } \\
\text { robo-advice are related to the positive opinion and } \\
\text { satisfaction of investors with robo-advice. The type } \\
\text { of investment strategy in the study group did not } \\
\text { differentiate the level of investment amounts, fees } \\
\text { and robo-advice scores. People applying a conservative } \\
\text { strategy similarly assessed satisfaction with } \\
\text { robo-counselling as those using a balanced and } \\
\text { aggressive strategy. }\end{array}$ \\
\hline
\end{tabular}




\begin{tabular}{|l|l|l|l|}
\hline 2020 & $\begin{array}{l}\text { K. Waliszew- } \\
\text { ski } \\
\text { A. Warchlew- } \\
\text { ska }\end{array}$ & $\begin{array}{l}\text { Representa- } \\
\text { tive group of } \\
\text { Poles }\end{array}$ & $\begin{array}{l}\text { Analysis of data obtained from customer surveys } \\
\text { assessing their expectation with the use of modern } \\
\text { technologies indicates that the vast majority of respon- } \\
\text { dents would not be happy if a computer program made } \\
\text { investment decisions on their behalf. At the same time, } \\
\text { the respondents mostly expressed a willingness for } \\
\text { a computer program to analyse their spending habits } \\
\text { and recommend improvements. Practical Implications: } \\
\text { Study showed that level of education did not affect the } \\
\text { assessment of robo-advice concerning investment deci- } \\
\text { sions, but it did influence willingness to receive invest- } \\
\text { ment proposals. People with higher education would } \\
\text { be more likely to use a computer program that would } \\
\text { analyse their expenses and suggest improvements. }\end{array}$ \\
\hline
\end{tabular}

Source: Kordela (2018): 54; Fulk et al. (2018): 180; Beketov, Lehmann, Wittke (2018): 366; Woodyard, Grable (2018): 40; Waliszewski, Warchlewska (2020a): 110-112; (2020b): 900-902; (2020c): 399-420.

The overview of the robo-advice survey provided presents several important conclusions. Considering the most developed American market, only about five per cent use robo-advice services. Only the robo-advisor's fees and costs are rated better than those of the human advisor. The advantages of human advisors include simplifying the investing process for investors, more reliability in turbulent markets, matching clients' investments to their risk tolerance, focusing on investors' best interests, making good investment recommendations, taking each client's entire financial picture into account, advising clients on the risks they are taking, making people feel confident about their investments, and helping people understand their investments. The results showed that users of robo-advisory services compared with users of traditional financial planning generally had lower income and lower net worth, had received no or less inheritance and were less impulsive financially. In addition, Modern Portfolio Theory is the dominant theory used by RAs (about $40 \%$ of the 219 platforms studied). On the German market, it is mostly (over $40 \%)$ active asset management that is offered, while passive or both account for $20 \%$ each. Most digital platforms in Germany are at the 3.0 stage of evolution in robo-advice. Users of robo-advisory services are young and confident in their financial abilities, yet distrustful of traditional channels of financial advice.

\section{ROBO-ADVICE VS HUMAN ADVICE: PRIMARY RESEARCH}

In order to verify the research hypothesis put forward in the introduction to the article, the authors conducted an empirical study among 19 traditional financial advisers holding the EFG (European Financial Guide) certificate, 12 advisers holding the EFC (European Financial Consultant), and 9 advisers associated in the European Federation of Financial Professionals EFFP Pol- 
ska. The study was conducted in March-May 2020 through Google surveys, under the patronage of the European Federation of Financial Professionals EFFP Poland.

Traditional financial advisers were asked whether robo-advice is a threat to traditional financial advisory. Nearly $53 \%$ of the surveyed advisers indicated no, and $47 \%$ said yes. Next, advisers were asked whether robo-consulting can support traditional financial consulting. Over $68 \%$ of the respondents indicated yes, and the rest indicated that they did not (Graph 1).

\section{Graph 1}

Threats to traditional financial consulting from robo-advice

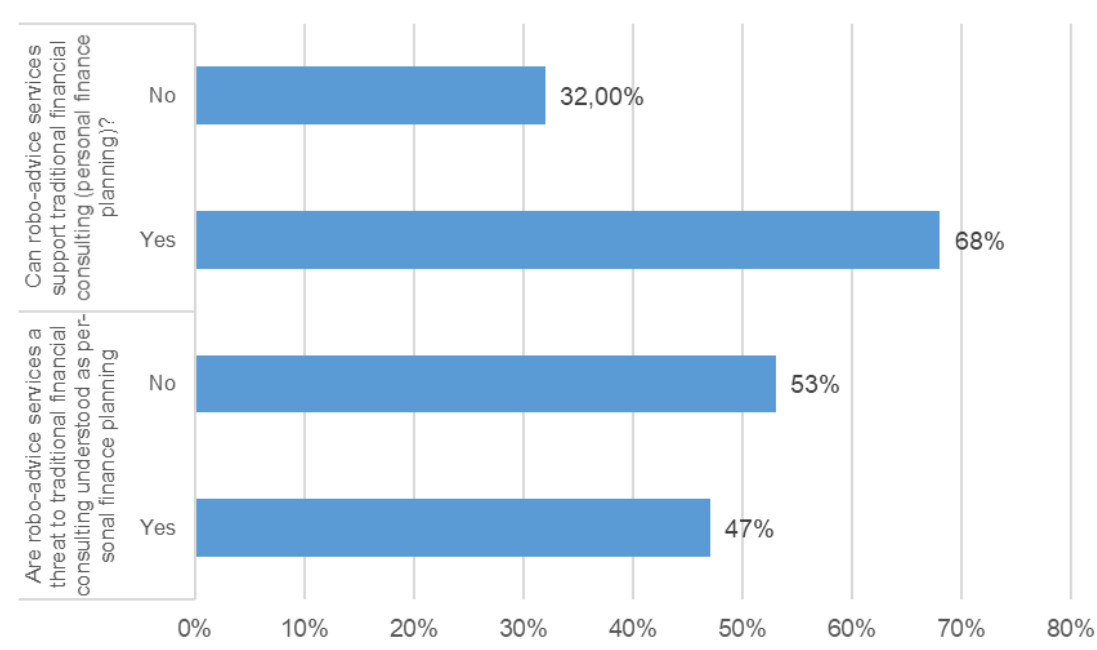

Source: the authors' own study.

The next question focused on the prospects for the development of roboconsulting in Poland. Almost 58\% of advisers described the prospects as positive, while $31.6 \%$ described them as positive, $15.8 \%$ rather positive, and $10.5 \%$ definitely positive. At the same time, nearly $42 \%$ of respondents described the outlook as negative, $36.8 \%$ as rather negative, and $5.3 \%$ as definitely negative (Graph 2).

Taking into account the global trends related to the use of robo-consulting by traditional financial advisers, the respondents were asked whether they agreed with the statement that the future belongs to a hybrid consulting model in which a traditional advisor uses modern technologies and robo-advice as a tool in his or her work with the client? Nearly $58 \%$ of the respondents agreed with this statement, and $42 \%$ disagreed with it.

The most important advantages associated with robo-consulting were traditionally indicated by advisers: low costs associated with consulting (57.9\%), high service availability (47.40\%), the possibility of passive investing (26.30\%), 


\section{Graph 2}

What are the prospects for the development of robo-advice in Poland?

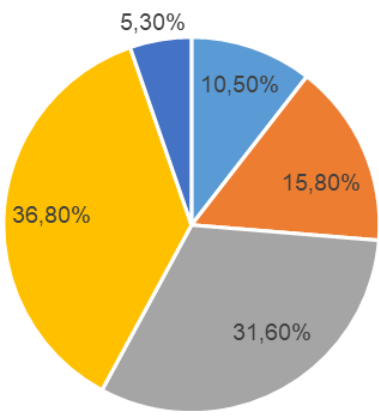

- Definitely positive " Rather positive "Positive "Rather negative - Definitely negative

Source: the authors' own study.

and low minimum investment amount (10.50\%). At the same time, the most important disadvantages of robo-consulting were indicated by traditional advisers: no full fit to individual needs (73.70\%), no contact with a human advisor $(63.20 \%)$, low trust from customers (52.60\%), low transparency $(42.10 \%)$, limited offer (26.30\%) (Graph 3).

\section{Graph 3}

The most important advantages and disadvantages of robo-advice in the opinion of human advisors

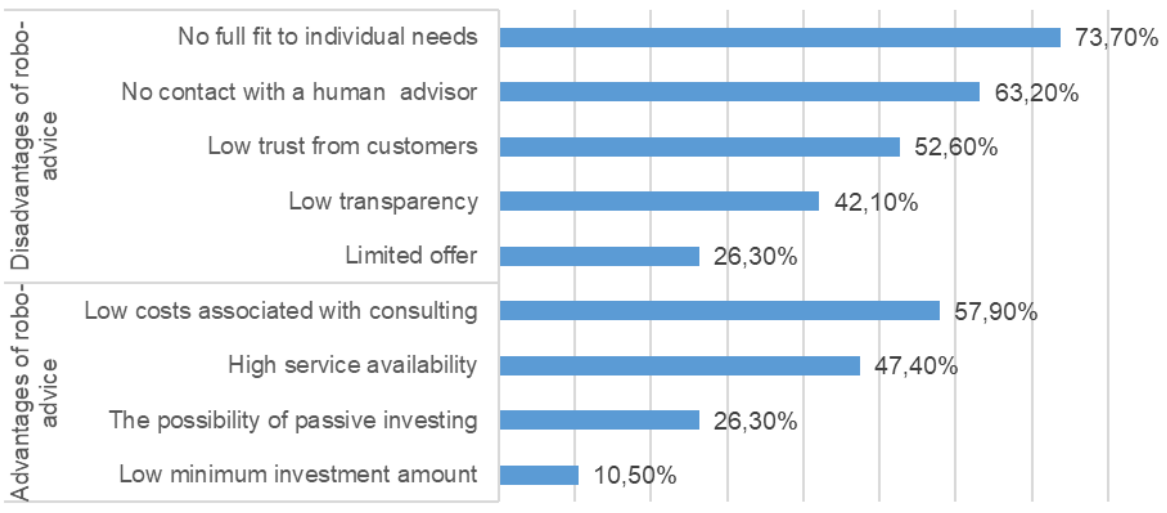

$0,00 \% 10,00 \% 20,00 \% 30,00 \% 40,00 \%[0,00 \% 60,00 \% 70,00 \% 80,00 \%$

Source: the authors' own study.

Traditional financial advisors have an advantage over robo-advisors in factors that are crucial for using the services of external specialists: trust, 
adaptation to the needs and expectations of clients and direct contact between the client and the adviser. In addition, traditional financial advisers offer comprehensive personal finance planning services, and robo-advisers are limited to investment advisory services.

\section{CONCLUSION}

The development of modern technologies is fastest in the area of retail financial services. Thanks to modern technologies, household members have a chance to make optimal financial decisions. The emergence of FinTech entities in the market is a response to the changing market and to the gap in the offer of remote service and financial management that the banking sector offers

The analysis of robo-advice applications leads to the conclusion that modern solutions still struggle with the great distrust of their current and potential customers. The analysis of the benefits and possible drawbacks of the presented concepts shows that modern solutions support customers in personal financial planning in the area of liquidity and asset management. At the current stage of the development of FinTech solutions, the human factor is still necessary. The authors' research confirms that robo-advice has some advantages, but also many disadvantages. However, most traditional counselors see them not as a threat, but as an opportunity and tool for work in the future. The most probable application in the near future is the hybrid model, in which a traditional advisor uses modern technologies and robo-advice as a tool for his or her work with the client. Most human advisors assessed the prospects for the development of robo-consulting as positive. The hybrid model is also popular abroad, where the largest robo-advisers, such as Personal Capital and Betterment, give clients the opportunity to contact a traditional, human financial advisor.

Krzysztof Waliszewski

Poznań University of Economics and Business

krzysztof.waliszewski@ue.poznan.pl

https://orcid.org/0000-0003-4239-5875

Anna Warchlewska

Poznań University of Economics and Business

anna.warchlewska@ue.poznan.pl

https://orcid.org/0000-0003-0142-7877

Beketov, M., Lehmann, K., Wittke, M. (2018). Robo advisors: quantitative methods inside the robot. Journal of Asset Management 19: 363-370.

Brenner, L., Meyll, T. (2020). Robo-advisors: a substitute for human financial advice? Journal of Behavioral and Experimental Finance 25(March): 1-8.

Cichowicz, E. (2016). Wykorzystanie nowoczesnych technologii przez instytucje finansowe w procesie przeciwdziałania wykluczeniu finansowemu. Annales. Etyka w życiu gospodarczym. 19(1): 71-82. 
Deloitte (2016). Robo-Advisory in Wealth Management. <www2.deloitte.com/content/dam/Deloitte/de/Documents/financial-services/Robo_No_2.pdf> [accessed 20 March 2020].

Dorfleitner, G., Hornuf, L., Schmitt, M., Weber, M. (2017). FinTech in Germany. Springer International Publishing AG: 13-54.

Facundo, A., Schmukler, S.L., Tessada, J. (2019). Robo-advisors: Investing through Machines (English). Research \& Policy Briefs; no. 21. Washington, D.C.: World Bank Group. <http:// documents.worldbank.org/curated/en/275041551196836758/Robo-Advisors-Investingthrough-Machines [accessed 15 March 2020].

Faloon, M., Scherer, B. (2017). Individualization of robo-advice. Financial Analysts Journal 47(12): 30-36. doi:10.2469/dig.v47.n12.1

Fein, M.L. (2015). Robo-Advisors: A Closer Look, June 30. <https://papers.ssrn.com/sol3/papers. cfm?abstract_id=2658701> [accessed 15 March 2020].

Fulk, M., Grable, J.E., Watkins, K., Kruger, M. (2018). Who uses robo-advisory services, and who does not? Financial Services Review 27(2): 173-188.

Górna, S., Warchlewska, A. (2018). Nowoczesne technologie jako czynnik konkurencji na lokalnych rynkach usług bankowych (na przykładzie Gospodarczego Banku Spółdzielczego Międzyrzecz). Optimum. Economicum Studies 1(91): 283-305.

ISO 22222-2005 - Personal Financial Planning. Requirements for personal financial planners

Jajuga, K., Feldman, Ł., Pietrzyk, R., Rokita, P. (2015). Integrated Risk Model in Household Life Cycle. Wrocław: Wydawnictwo Uniwersytetu Ekonomicznego we Wrocławiu.

Jung, D., Dorner, V., Glaser, F., Morana, S. (2018). Robo-advisory: digitalization and automation of financial advisor. Business \& Information Systems Engineering 60: 81-86.

Jung, D., Glaser, F., Köpplin, W. (2019). Robo-advisory: opportunities and risks for the future of financial advisory, [in:] V. Nissen (ed.), Advances in Consulting Research. Recent Findings and Practical Cases. Springer Nature Switzerland AG: 405-427.

Kordela, D. (2018). Robo-advisors in asset management - the experience from Germany. European Journal of Service Management 4(28/1): 151-157.

Lusardi, A., Mitchell, O.S. (2011). Financial Literacy and Retirement Planning in the United States. Netspar Discussion Paper No. 02: 1-36.

Madir, J. (ed.) (2019). FinTech: Law and Regulation. Edward Financial Law and Practice.

Madura, J. (2014). Personal finance. Fifth edition. Pearson Education.

Madura, J., Casey, M., Roberts, S. (2014). Personal Financial Literacy. Pearson.

Milic-Czerniak, R. (2019). Rola fintechów w rozwoju innowacji finansowych. Studia BAS 1 (57): 37-60.

Mitek, Ł. (2016). Household Financial Planning with Financial Advisory Assistance. Współczesne Finanse. Teoria i Praktyka: 73-82.

Musiał, M. (2015). Zastosowanie instrumentów zarządzania finansami osobistymi w polskich gospodarstwach domowych. Kwartalnik Kolegium Ekonomiczno-Społecznego Studia i Prace 3.4: 233-243.

Musiał, M. (2018). Efektywność gospodarowania finansami osobistymi w Polsce. Wydawnictwo Naukowe Uniwersytetu Szczecińskiego. Szczecin.

Pietrzyk, R., Rokita, P. (2018). Pomiar ryzyka planu finansowego gospodarstwa domowego. Annales Universitatis Mariae Curie-Skłodowska Sectio H - Oeconomia 4(52): 59-71. doi:10.17951/h.2018.52.4.59-7

Report FinTech: Regulatory sandboxes and innovation hubs. (2018). The European Supervisory Authorities (ESAs). JC 201874

Samsel, A. (2019). Planowanie jako element zarządzania budżetem gospodarstw domowych. Rozprawy Ubezpieczeniowe 1: 57-68.

Swacha-Lech, M. (2016). Wiedza finansowa jako jedna z determinant długoterminowego planowania finansowego. Annales Oeconomia L, 4: 477-485. doi:10.17951/h.2016.50.4.477

Świecka, B. (2018). Kompetencje finansowe i edukacja finansowa. Ujęcie teoretyczne i praktyczne. Rozprawy Ubezpieczeniowe 1: 3-17.

Świeszczak, K. (2017). Zaufanie w świecie finansów w obliczu rozwoju technologii na przykładzie banków i sektora FinTech. Bezpieczny Bank 2: 143-158. 
Waliszewski, K. (2014). Planowanie finansów osobistych (zarządzanie finansami osobistymi) z udziałem doradców finansowych - znaczenie dla gospodarstw domowych i gospodarki. Problemy Zarządzania 12(4): 204-221.

Waliszewski, K. (2016). Model doradztwa w obszarze finansów osobistych w Polsce na tle doświadczeń międzynarodowych. Poznań: Wydawnictwo Uniwersytetu Ekonomicznego w Poznaniu.

Waliszewski, K., Warchlewska, A. (2020a). Who uses robo-advisors? The Polish case. European Research Studies Journal 23(Special Issue 1): 97-114. doi:10.35808/ersj/1748

Waliszewski, K., Warchlewska, A. (2020b). Socio-Demographic Factors Determining Expectation Experienced while Using Modern Technologies in Personal Financial Management (PFM and robo-advice): A Polish case. European Research Studies Journal 23(Special Issue 2): 893-904. doi:10.35808/ersj/1904

Waliszewski, K., Warchlewska, A. (2020c). Attitudes towards artificial intelligence in the area of personal financial planning: a case study of selected countries. Entrepreneurship and Sustainability 8(2): 399-420. doi:10.9770/jesi.2020.8.2(24)

Wiśniewska, A. (2016). Determinanty nadmiernego zadłużania się polskich gospodarstw domowych. Współczesne Finanse. Teoria i Praktyka 1: 91-100.

Włodarczyk-Śpiewak, K. (2011). Nowoczesne technologie - wyzwanie dla współczesnych konsumentów. Studies \& Proceeding of Polish Assiociation for Knowledge Management 51: 143-152.

Woodyard A.S., Grable, J.E. (2018). Insights into the users of robo-advisory firms. Journal of Financial Service Professionals 72(5): 56-66.

www.statista.com [accessed 17 March 2020]

\section{FINANCIAL TECHNOLOGIES IN PERSONAL FINANCIAL PLANNING: ROBO-ADVICE VS. HUMAN-ADVICE}

\section{Sum mary}

The paper presents the essence of financial technologies in personal financial planning, especially robo-advice. The main aim of the paper is to describe the presumptions for the development of robo-advice. An analysis of robo-advice on personal finance management was made. The analysis was based on a review of the subject literature, and on primary and secondary research. Particular attention was paid to the intensification of activities in the implementation of modern solutions and tools supporting the management of personal finances and the gradual development of robo-advisors. Modern solutions are still struggling with great distrust on the part of their current and potential customers, and the development of modern technologies in liquidity and asset management still requires a human factor.

Keywords: personal financial planning; fintech; robo-advice; human advice; JEL codes: D10, G20, G50, L84, O33 
